\title{
Lateral Decubitus Position
}

National Cancer Institute

\section{Source}

National Cancer Institute. Lateral Decubitus Position. NCI Thesaurus. Code C100758.

Lying down or reclining with one side of the body in a downward direction. 